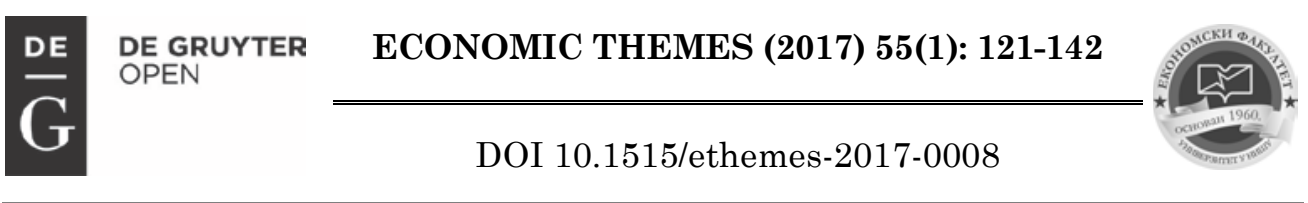

\title{
INTEGRATED AHP-TOPSIS METHOD FOR THE ASSESSMENT OF HEALTH MANAGEMENT INFORMATION SYSTEMS EFFICIENCY ${ }^{1}$
}

\author{
Žarko Rađenović \\ University of Niš, Faculty of Economics, Republic of Serbia \\ $\bowtie$ zarkoradjenovic@hotmail.com

\section{Ivana Veselinović} \\ University of Niš, Faculty of Economics, Republic of Serbia \\ i_veselinovic@yahoo.com
}

UDC

614:004.73

8.5

Review

paper

\begin{abstract}
The aim of this paper is to analyse and estimate the efficiency of health information systems in the provision of health care services. The evaluation of health information systems is conducted in the case of three most widely used softwares in the electronic health care. This evaluation is based on multi-criteria analysis of the health information systems efficiency using the AHP-TOPSIS method. This method, based on common attributes and their respective values for all three software solutions, individually determines the best rated software solution. Top rated software solution of electronic health care is not necessarily the best for the implementation and development, given the fact that each health care organisation has its own characteristics. Functional and evolutionary-minded hardware and software applicative infrastructure contributes to the consistency of electronic health concept that all system users provides a comfortable software solutions, which ultimately leads to the timely and quick medical services in real time.
\end{abstract}

Received: Keywords: multi-criteria analysis, AHP, TOPSIS, e-health, health

18.10.2016. management information systems, efficiency.

Accepted:

16.03.2017.

\footnotetext{
1 Acknowledgement: The paper is a result of the research within projects 41010 and 179066, funded by the Ministry of Education, Science and Technology of the Republic of Serbia.
} 


\section{Introduction}

The task of selecting the optimal information system has become very complex in modern conditions for several reasons (Zaidan et al, 2015). First, it is difficult to adequately assess which information system is optimal as there is a large number of different information systems in the market. Furthermore, there is a problem of non-compliance of the existing hardware and desired software solution. Also, the lack of technical knowledge and experience of decision makers can pose a problem. Another one of the problems that decision makers discover in the present conditions when it comes to the selection of the information system is the rapid progress of information technology.

Development of information systems and growing trends in the industry of information technology have enabled their application in health organisations in order to increase the provision of health services. During the development and implementation of information systems to support electronic health care is extremely important to choose the best alternative among many that exist in the market. Proper selection of the health information system will provide not only the cost and operational efficiency, but also better communication among health care organisational units and a higher degree of interoperability, collaboration and coordination. In this way, information systems (multi-stakeholder approach) in health care organisations provide a higher level of quality of services resulting from adequately collected and analysed information on the health status of patients.

Evolution of information technologies and trends in this industry have enabled the use of information as a resource without which one cannot imagine the efficient operation of an organisation and its market recognition. Information creates competitive advantages and makes the difference between successful and unsuccessful companies on the market orbit. Management information systems for the electronic health care support is also a result of the need to take the same health organisations differentiate itself in the market, providing high quality and cost effective health care services (Rodrigues, 2000). Information systems in health care organisations contribute to better monitoring of patients' medical history and giving users analytical tools for forecasting the future state of the disease. Also, in electronic health information exchange is facilitated by giving the space for the exchange of opinions of medical personnel which may not be geographically linked.

The structure of a concrete health organisation defines the use of software solutions for the implementation of the e-health concept. Functional and evolutionary-minded hardware and software applicative infrastructure contributes to the consistency of the concept of electronic health that all users of the system provides a user friendly attitude towards software solution, which ultimately leads to the provision of timely and quick medical services in real time. In this way, the selection of adequate software solution provides the ability to better health care 
with respect to collecting and analysing large amounts of information can monitor patients' medical histories.

Implementing the system for electronic support in health care organisations is facilitating and professionalising the business environment. Using modern software solutions offers a better service and a more efficiency in organisation resources using. The development of systems for electronic support in health care organisations prevents the occurrence of errors due to software equipment of precise presentation and documents archiving. Rising operational efficiency and the level of collaboration as well as the monitoring and control of both diseases improves traffic consumed medical supplies (Rodrigues 2003). Classification, transformation, verification and sending information about the health status of patients, the state of stocks of medical supplies and equipment, as well as monitoring the distribution of financial, organisational and human resources are the key activities of the process of virtualisation of health services. The activities mentioned development and implementation of information systems in health care organisations, which handles large amounts of data, use the GIGO (garbage in garbage out) principle of acquisitions of health data.

The introduction of electronic health records as an integral part of e-health in the health organisations solves the problem of data acquisition for patient monitoring (with guaranteed protection of privacy). The flow of multimedia content enables superior communication between medical teams and the opinion exchange on the provision of quality health services with the cost reduction at all levels. Identification of problems and challenges in the possibilities evaluation for implementing systems in health care organisations is very important in order to timely eliminate the so-called bottlenecks of the process when introducing new software solutions. They arise due to inadequate adjustment of health care information user to new conditions (Mitchell, 2003). Providing adequate and representative methodology for assessing the ability of healthcare organisations to implement a HMIS concept (Health Management Information Systems) is a basic principle of work of the electronic health information systems. This is because the multi-stakeholder approach requires precision, clarity, transparency and security in using and analysing health information, with the aim of providing better health protection and preventive actions in case of certain diseases (Rodrigues, 2003).

This kind of virtual communication within health organisations with web orientation allows a higher degree of coordination and collaboration between staff and patients. Also, the information systems in electronic health promote the process of managing financial resources and organisational capital. Proper selection of software solutions, which are in the market proved to be the most effective, and taking into account the organisational characteristics, creates a virtual health community that adds a new dimension of cost-effective health services and providing better health care. Information Systems in electronic health 
support the process of managing financial resources and organisational capital. In this way, the development and implementation of information systems of this kind comes to the integration of the same with a SCM (Supply Chain Management) and CRM (Customer Relationship Management) date healthcare organisations all of which leads to the productive process of planning and management of resources of the organisation (ERP - Enterprise Resource Planning).

Information systems for the e-business health organisations support in the foreseeable future will be widely predominated solutions for effective communication to healthcare organisational units with each other and with patients. This will improve the delivery of health services in terms real time actions, based on the analysis of patients case histories daily monitoring and large amounts of data in real time (Tan et.al, 2010). By creating a virtual health networks and communities improves the exchange of opinions of medical personnel and the transfer of knowledge, modern equipment, medicines and medical supplies. The concept of the electronic health card in virtual communities helps organisations to accomplish cross-border cooperation in order to effective treatment of patients and preventive actions.

In order to achieve all the above benefits of electronic health an organisation must implement a complete analysis of their abilities, capacities and structures. This is because, for the proper functioning and use of the concept of e-health in order to provide better health services and life, it is necessary to choose that software alternative in the market which will best suit organisational performance. Selected information system of electronic health care aims to raise the performance of healthcare organisations to a higher level, but it is necessary that all the organisational sectors and stakeholders get involved in the implementation process. The evolutionary approach of the electronic health care organisation is also important due to the fact itself realizes over time its development potential and possible work inconsistencies that should be improved or eliminated using adequate health information system. Therefore, the electronic health monitoring trends and their relationship with organisational features represents significant activity in order to choose a real alternative of ready-made software solutions.

For the purpose of testing the starting hypotheses, quantitative methodology was applied in the paper. The paper has two structural parts. The first part provides an overview of theoretical and empirical considerations of the effects of FDI inflow and measuring of company's performance. The second part elaborates the results of the conducted research.

\section{Theoretical Background}

Area of evaluation and selection of the information system has become a subject of interest for many researchers because the process of selecting an adequate 
information system which meets the specific needs of particular institutions is complicated and time-consuming task bearing in mind the need to fulfil several criteria. Also, the choice will be different depending on the point of view of decision-makers, since not all users are interested in the same goals (the doctors are primarily interested in the selection of user-friendly system, nurses are interested in systems that allow easy entry and manipulation of data, economists want that installed system quickly realises a return on investment, while information professionals are interested in building a system that works and that is reliable within given limits). Selection of wrong information system cannot only represent an unjustified expenditure, but can also have a negative impact on business processes and the functioning of the institution. Therefore, the main objective of this paper is to present one of the approaches for evaluating health information systems using the multi-criteria decision making methods.

This paper will employ TOPSIS method as a multi-criteria analytical tool for assessing the development and implementation of the best alternative among the current software solutions on the market of medical information systems. TOPSIS method is different from other, alternative methods, because it is easy to understand and use, but at the same time very effective, and it takes into account the ideal and anti-ideal solution. In this method, the number of steps for its implementation is the same regardless of the number of alternatives and criteria. Unlike other methods, ranking of alternatives is numerical value, which allows a better understanding of the results. TOPSIS method is efficient in solving problem of ranking, compared to other methods (Anojkumar, L. et al., 2014). The most commonly used alternative method for TOPSIS is ELECTRE method, but there are other methods for ranking that can be used such as PROMETHEE, SAW, MOORA or VIKOR. The failure of TOPSIS is that it does not take into account the correlation between criteria and the relative distance between the ideal and antiideal solution (Jahan, A. \& Edwards, 2014).Based on the list of the top 20 most used software solutions at the start of 2016, according to data from the EHR in Practice, in electronic health, the authors have decided to analyse and rank the performance of three software solutions:

- eClinical Works - software solution for the implementation of the concept of electronic cards (EHR- Electronic Health Record). It is used as a platform for providing services based on electronic health care with adequate monitoring and analysing information about the history of the disease even on mobile devices. It respects HIPPA standardisation and allows web orientation, which provides the basis for cloud approach to data organising;

- CureMD - platform solely based on cloud orientation for information management based on big data concept. It uses HL7 standardisation and enables the efficient flow of documentation, medical supplies and exchange of opinions. Also, its multi-stakeholder approach provides insight 
into other institutions' information about the particular patient (insurance companies, local authorities, ministries, educational and scientific research institutions). It provides the necessary data security and privacy in the context of stakeholder data exchange. It also creates a space for effective communication with laboratories and development of pharmacoinformatics.

- McKesson Practice Choice - a software solution that is mainly used for medical centres with fewer employees $(<50)$ in order to increase cost effectiveness and the degree of coordination. Also, the platform on which this software solution is based enables better communication of patients and medical staff in real time and consequently the increase of health services quality. Due to this, the future course of the disease can be predicted and further analysed because of the small number of stakeholders involved in the use of information which gives a higher level of commitment and attentiveness in providing health services to patients.

For evaluation of software solutions for electronic health the following criteria were taken into account:

- Number of users of information systems for support to electronic health $\left(\mathrm{C}_{1}\right)$;

- Data redundancy on an annual basis in the preparation and encoding electronic invoices $\left(\mathrm{C}_{2}\right.$;

- Monthly increase of interoperability rates at the beginning of the implementation period $\left(\mathrm{C}_{3}\right)$;

- Rate of return on investment in communication infrastructure on a monthly basis in the year of implementation of electronic health $\left(\mathrm{C}_{4}\right)$;

- Monthly increase of the utilization of data (big data) based on cloud approach and web orientation in percentage $\left(\mathrm{C}_{5}\right)$;

- Assessment of compliance with HIPPA principles on a scale of 0-10 $\left(\mathrm{C}_{6}\right)$.

Multiple criteria decision making represents a process of solving the problem of selection one among several alternatives that are evaluated by using several criteria (Yoon \& Hwang, 1995). Evaluation and selection of information systems can be seen as multi-criteria decision making problem and therefore for their resolving multi-criteria methods can be used. Many methods for solving the problem of multi-criteria decision making require clearly defined and expressed weighting coefficients. Weighting coefficients represent the importance of each attribute, i.e. the contribution of each of the attributes to the achievement of the final goal. Therefore, evaluation and allocation of weights plays a key role in the process of multi-criteria decision making and varies depending on decision makers qualities. 
Weighting coefficients should be in accordance with the purpose of analysis. Also, the weights themselves represent useful information for those who evaluate solutions for specific problems solved by multi-criteria decision making methods, as they quantitatively indicate preferences of decision makers. Area of weights determination occupies the attention of many researchers. In the literature one can find several works that propose a specific method for calculating the weight coefficients. Among the methods that are commonly found in literature we can single out Trade-off method (Milićević \& Župac, 2012, Arnesen \& Trommald, 2004; Poyhonen \& Hamalaien, 2001), SMART method and modifications of this method SMARTS and SMARTER (Edwards \& Barron, 1994; Ward \& Hutton, 1994; von Winterfeldt \& Edwards, 1986; Barron \& Barrett, 1996), the AHP method (Rao, 2008; Saaty, 1990; Rao \& Davim, 2008; Podvezko \& Sivilevičius 2013), Entropy method (Zavadskas \& Podvezko, 2016; Wu et al., 2011; Chin et al., 2015), CRITIC method (Milićević \& Župac, 2012; Diakoulaki et al., 1995; Deng et al., 2000), Delphi method (Pulipati \& Mattingly, 2013; Curtis, 2004), Conjoint method (Danaher, 1997), MACBETH method (Kundakc1 \& Iş1k, 2016; Kundakc1, 2016; Karande \& Chakraborty, 2014; e Costa \& Vansnick, 1997), Direct rating (Bottomley \& Doyle, 2001; Roberts \& Goodwin, 2002), FANMA method (Milićević \& Župac, 2012; Krstić et al, 2015; Srđević, 2005, Ma et al., 1999), Weighted Least-Square Method (Xu, 2004).

Some of these methods give importance to the subjective assessment of decision makers, while others rely on exact scientific method. Regardless of the method for determining weighting coefficients, one thing is certain, their impact on the final ranking of alternatives is very important, therefore, determining the weighting coefficients should be approached with great seriousness.

Bearing in mind the fact that the subject of evaluation is the health information system we have reviewed the literature related to information systems and found the AHP method application in numerous works (Ahmadi et al, 2014; Wei et al., 2005; Colombo \& Francalanci, 2004; Lee \& Kim, 2000; Kim \& Moon, 1997; Ngai \& Chan, 2005; Teltumbde, 2000) and also the application of TOPSIS method (Huang, 2008; Kim \& On, 2014). Therefore these methods will be applied in this paper for assessment of effectiveness of health information systems. An integrated the AHP-TOPSIS method will be applied, where the AHP method will be used for weighting coefficients determination while the final ranks of observed alternatives will be determined by TOPSIS method.

\section{Methodology}

Method of Analytical Hierarchy Process (AHP) was developed by Thomas Saaty in early seventies. The AHP is a tool in the analysis of decision-making, designed to 
assist decision makers in solving complex problems involving a larger number of decision-makers, as well as numerous criteria.

The AHP method is based on well-defined mathematical structure that allows the determination of eigenvectors based on which relatively accurate or accurate weights are generated (Jayant et al, 2014). Method of Analytical Hierarchy Process makes the comparison of criteria or alternatives taking into account the criteria, by pairs. In addition, this method uses proven numerical scale that represents individual preferences, taking into account both quantitative and qualitative attributes (Saaty, 1980, 1994). In this way, the individual preferences are transformed into ratio scale.

The essence of the method is to create a hierarchical structure from a complex decision problem that may contain multiple criteria, multiple alternatives as well as the increasing number of decision makers, determining the weights of criteria and alternatives by levels and thus form a final ranking of alternatives. The process of modelling requires four phases (Saaty, 1980 specified in (Zaidan et al, 2015)):

1. Creating a hierarchical structure i.e. determination of alternatives, criteria and sub-criteria

2. Collection of data through pairwise comparison in order to create a decision-making matrix

3. Evaluation of relative weights

4. Adoption of the final decision

The first phase involves the decomposition of the decision problem. The problem is observed as a hierarchy, where at the very top the goal of the problem is located, while the criteria and possibly sub-criterion, depending on the complexity are placed at the lower levels. A set of alternatives which are the objects of the assessment are positioned at the lowest level of the hierarchy is.

The second phase of the AHP method involves the collection of data and pairwise comparison of the elements of hierarchical structures, both at a given level of hierarchy, and in relation to the criterion of the immediately higher level. The essence of pairwise comparisons is to determine the preferences which decision maker expresses through Saaty's scale of relative importance.

Table 1. Saaty's scale of relative importance

\begin{tabular}{|l|l|}
\hline Intensity & Definition \\
\hline 1 & Equal importance \\
\hline 3 & Moderate importance \\
\hline
\end{tabular}




\begin{tabular}{|l|l|}
\hline 5 & Strong importance \\
\hline 7 & Demonstrated importance \\
\hline 9 & Extreme importance \\
\hline $2,4,6,8$ & Mean values between two adjacent assessments \\
\hline
\end{tabular}

Source: Saaty, 1980

The result of this process is the appropriate comparison matrix which represents the beginning of the third phase of the AHP method. The third phase of the AHP method consists in assessing the relative weights. Pairwise comparison from the second phase results in a reciprocal $n \times n$ matrix $A$, where the elements on the main diagonal are $a_{i i}=1$, and the elements $a_{j i}$ are calculated as the reciprocal of the elements $a_{i j}$, ie. $a_{j i}=\frac{1}{a_{i j}}, i \neq j$, and $i, j=1,2, \ldots, n$ (Janković-Milić \& Stanković, 2010).

As a result of this comparison, in the fourth phase, on the criteria level, one can determine the relative importance of each criterion, expressed through the weighting coefficient. On the other hand on the level of alternatives it is possible to determine the ranking of alternatives for each of the monitored criteria. Advantages of the AHP method (Jadhav \& Sonar, 2009):

- The AHP allows decision-makers decompose decision problems into hierarchy, making it easier to understand and also performing the simplification of the problem;

- It represents a flexible and powerful tool for combining both quantitative and qualitative multi-criteria problems;

- The AHP method can be applied into situations of individual and group decision making.

Disadvantages of the AHP method (Jadhav \& Sonar, 2009):

- The AHP method is time-consuming since it is necessary to perform mathematical calculations and a number of pairwise comparisons whose number increases with the increase of number of criteria and alternatives;

- Decision makers must re-evaluate their decisions if the number of alternatives or criteria changes;

- Rank of the alternatives depends on the number of considered alternatives and addition or deletion of some of the alternatives leads to changes in the final order. 
In this paper, the AHP method will be used to determine the weight coefficients, while setting priorities, i.e. ranking of alternatives will be carried out by using the TOPSIS method.

The name of the TOPSIS method represents an acronym for The Technique for Order of Preference by Similarity to Ideal Solution. The ideal solution is the point at which the utility for decision-makers is the largest, that is, the point at which income attributes have the highest value, while expenditure attributes have the lowest value (Todorović \& Stankovic, 2011).

The TOPSIS method is a multi-criteria analysis method developed by Hwang and Yoon in 1981 (Hwang \& Yoon, 1981). TOPSIS method evaluates alternatives, i.e. performs prioritisation of alternatives based on their geometric distance from the positive-ideal and negative-ideal solution. Accordingly, it can be concluded that the best alternative will be the one with the shortest distance to the positive-ideal solution, and with the greatest distance from the negative-ideal solution. The TOPSIS method involves the use of specific steps (Yoon \& Hwang, 1995):

Step 1: Determination of normalised decision matrix $\mathrm{R}$ with coefficients $r_{i j}$ obtained by vector normalisation.

$$
r_{i j}=\frac{x_{i j}}{\sqrt{\sum_{i=1}^{m} x_{i j}^{2}}} i=1,2, \ldots, \mathrm{m}, j=1,2, \ldots, \mathrm{n} .
$$

Step 2: Determination of weight normalised decision matrix V with coefficients $v_{i j}$ which are calculated by multiplying each element of each column of the normalised decision matrix by the adequate weights:

$$
v_{i j}=r_{i j} w_{j}
$$

In this paper weightings were introduced from the AHP (Analytical Hierarchy Process) technique to quantify the relative importance of the different selection criteria.

Step 3: Determination of positive ideal and negative ideal solution. The values $\mathrm{v}_{\mathrm{j}}{ }^{*}$ and $\mathrm{v}_{\mathrm{j}}{ }^{-}$which describe positive ideal solution $A^{*}$ and negative ideal solution $A^{-}$ are defined as:

$$
A^{*}=\left\{v_{1}^{*}, v_{2}^{*}, \ldots, v_{j}^{*}, \ldots, v_{n}^{*}\right\}=\left\{\left(\max _{i} v_{i j} \mid j \in J_{1}\right) \wedge\left(\min _{i} v_{i j} \mid j \in J_{2}\right), i=1,2, \ldots, m\right\}
$$




$$
A^{-}=\left\{v_{1}^{-}, v_{2}^{-}, \ldots, v_{j}^{-}, \ldots, v_{n}^{-}\right\}=\left\{\left(\min _{i} v_{i j} \mid j \in J_{1}\right) \wedge\left(\max _{i} v_{i j} \mid j \in J_{2}\right), i=1,2, \ldots, m\right\}
$$

Where $J_{1}$ represents the set of revenue criteria, and $J_{2}$ the set of expenditure criteria. Depending on the defined problem, it is possible to define set $J_{3}$, which represent a set of nonmonotonic criteria. In that case positive and the negative ideal solution would be defined as the most and the least preferred values for a given nonmonotonic category (Todorović \& Stanković, 2011).

Step 4: Calculation of the distance (Euclidean distance) of each alternative from the positive ideal and negative ideal solution. The distance from the positive ideal solution is calculated as:

$$
S_{i}^{*}=\sqrt{\sum_{j=1}^{n}\left(v_{i j}-v_{j}^{*}\right)^{2}}, \quad i=1,2, \ldots, m
$$

Similarly, the distance of alternative from the negative ideal solution is calculated as:

$$
S_{i}^{-}=\sqrt{\sum_{j=1}^{n}\left(v_{i j}-v_{j}^{-}\right)^{2}}, \quad i=1,2, \ldots, m
$$

Step 5: Calculation of the proximity index $\left(C_{i}^{*}\right)$, which represents relative proximity of alternative to the positive ideal solution. The index is calculated as:

$$
C_{i}^{*}=\frac{S_{i}^{-}}{S_{i}^{*}+S_{i}^{-}}, i=1,2 \ldots, m
$$

Proximity index takes values in range $0 \leq C_{i}^{*} \leq 1$. If $C_{i}^{*}=0$ the alternative represents a negative ideal solution, and if $C_{i}^{*}=1$ the observed alternative corresponds with the positive ideal solution.

Step 6: Ranking of the alternatives according to their proximity index. The optimum alternative is the one with the highest proximity index, and as such it represents the optimal decision, or preferred or optimal solution to the problem. 


\section{The Results of Empirical Research}

According to data from the EHR in Practice six relevant criteria for evaluating health information systems were established. Obtained values for each of the alternatives for the observed criteria are given in Table 2 .

Table 2. Decision matrix

\begin{tabular}{|l|l|l|l|l|l|l|}
\hline & \multicolumn{6}{|c|}{ Criteria } \\
\hline Alternative & $\mathrm{C}_{1}$ & $\mathrm{C}_{2}$ & $\mathrm{C}_{3}$ & $\mathrm{C}_{4}$ & $\mathrm{C}_{5}$ & $\mathrm{C}_{6}$ \\
\hline eClinical Works & 10,00 & 6,00 & 2,40 & 15,28 & 6,82 & 8,00 \\
\hline CureMD & 2,95 & 2,00 & 3,42 & 14,23 & 6,00 & 6,00 \\
\hline McKesson Practice Choice & 4,40 & 2,73 & 3,25 & 13,33 & 7,44 & 4,00 \\
\hline Criteria type & max & min & max & max & max & max \\
\hline
\end{tabular}

Source: EHR in Practice

Normalised decision matrix is obtained by vector normalisation of given data and presented in Table 3.

Table 3. Normalised decision matrix

\begin{tabular}{|l|l|l|l|l|l|l|}
\hline & \multicolumn{6}{|c|}{ Criteria } \\
\hline Alternative & $\mathrm{C}_{1}$ & $\mathrm{C}_{2}$ & $\mathrm{C}_{3}$ & $\mathrm{C}_{4}$ & $\mathrm{C}_{5}$ & $\mathrm{C}_{6}$ \\
\hline $\begin{array}{l}\text { eClinical } \\
\text { Works }\end{array}$ & 0,88367 & 0,01473 & 0,45340 & 0,61682 & 0,58084 & 0,74278 \\
\hline CureMD & 0,26068 & 0,04418 & 0,64610 & 0,57444 & 0,51100 & 0,55709 \\
\hline $\begin{array}{l}\text { McKesson } \\
\text { Practice } \\
\text { Choice }\end{array}$ & 0,38881 & 0,03237 & 0,61399 & 0,53810 & 0,63364 & 0,37139 \\
\hline
\end{tabular}

Next step requires creation of weighted normalised decision matrix. To determine the weight coefficients in this paper Analytical Hierarchy Process technique is applied. The importance of each criterion on a scale from 1 to 9 was 
obtained by subjective assessment of the authors and presented in Table 4. By doing so authors have considering the importance of the criteria in terms of profitability, that is the assumption is that decision maker is primarily interested in rapid return on investment.

Table 4. Rating of criteria

\begin{tabular}{|l|c|}
\hline Criterion & Score \\
\hline $\begin{array}{l}\text { The number of users of information systems for } \\
\text { support to electronic health }\left(\mathrm{C}_{1}\right)\end{array}$ & 7 \\
\hline $\begin{array}{l}\text { Data redundancy on an annual basis in the } \\
\text { preparation and encoding electronic invoices }\left(\mathrm{C}_{2}\right)\end{array}$ & 8 \\
\hline $\begin{array}{l}\text { Monthly increase of interoperability rates at the } \\
\text { beginning of the implementation period }\left(\mathrm{C}_{3}\right)\end{array}$ & 3 \\
\hline $\begin{array}{l}\text { Rate of return on investment in communication } \\
\text { infrastructure on a monthly basis in the year of } \\
\text { implementation of electronic health }\left(\mathrm{C}_{4}\right)\end{array}$ & 9 \\
\hline $\begin{array}{l}\text { Monthly increase of the utilisation of data (big data) } \\
\text { based on cloud approach and web orientation in } \\
\left.\text { percentage ( } \mathrm{C}_{5}\right)\end{array}$ & 5 \\
\hline $\begin{array}{l}\text { Assessment of compliance with HIPPA principles } \\
\text { on a scale of } 0-10\left(\mathrm{C}_{6}\right)\end{array}$ & 2 \\
\hline
\end{tabular}

Obtained scores for each of criteria are then compared based on Satty's scale. As the result of this process a comparison matrix was created:

Table 5. Comparison matrix

\begin{tabular}{|l|c|c|c|c|c|c|}
\hline & C1 & C2 & C3 & C4 & C5 & C6 \\
\hline C1 & 1,000 & 1,000 & 4,000 & 0,500 & 2,000 & 5,000 \\
\hline C2 & 1,000 & 1,000 & 5,000 & 1,000 & 3,000 & 6,000 \\
\hline C3 & 0,250 & 0,200 & 1,000 & 0,167 & 0,500 & 1,000 \\
\hline C4 & 2,000 & 1,000 & 6,000 & 1,000 & 4,000 & 7,000 \\
\hline
\end{tabular}




\begin{tabular}{|l|l|l|l|l|l|l|}
\hline C5 & 0,500 & 0,333 & 2,000 & 0,250 & 1,000 & 3,000 \\
\hline C6 & 0,200 & 0,167 & 1,000 & 0,143 & 0,333 & 1,000 \\
\hline
\end{tabular}

To determine the Eigen vector of comparison matrix, obtained values need to be normalised. The normalisation was performed in two steps. First, the elements of comparison matrix were summarised by columns, and then each of the elements from comparison matrix was divided by the sum of the column in which it is located.

$$
w_{i j}=\frac{a_{i j}}{\sum_{i=1}^{m} a_{i j}}, i, j=1,2,3,4,5,6
$$

Then obtained values were summarised by rows. The value of weight coefficient for a particular criterion was obtained by dividing the resulting sum with the number of rows for each criterion separately. In this way vector of priorities is attained and that vector represents the Eigen vector of the matrix.

$$
w_{j}=\frac{\sum_{j=1}^{6} w_{i j}}{6}, i, j=1,2,3,4,5,6
$$

Based on the obtained results it is possible to determine the weights of each criterion.

Table 6. Weight coefficients

\begin{tabular}{|l|l|}
\hline Criterion & Weight \\
\hline $\begin{array}{l}\text { The number of users of information systems for } \\
\text { support to electronic health }\left(\mathrm{C}_{1}\right)\end{array}$ & 0,208041 \\
\hline $\begin{array}{l}\text { Data redundancy on an annual basis in the } \\
\text { preparation and encoding electronic invoices } \\
\left(\mathrm{C}_{2}\right)\end{array}$ & 0,266682 \\
\hline $\begin{array}{l}\text { Monthly increase of interoperability rates at the } \\
\text { beginning of the implementation period }\left(\mathrm{C}_{3}\right)\end{array}$ & 0,050216 \\
\hline $\begin{array}{l}\text { Rate of return on investment in communication } \\
\text { infrastructure on a monthly basis in the year of }\end{array}$ & 0,331754 \\
\hline
\end{tabular}




\begin{tabular}{|l|l|}
\hline implementation of electronic health $\left(\mathrm{C}_{4}\right)$ & \\
\hline $\begin{array}{l}\text { Monthly increase of the utilisation of data (big } \\
\text { data) based on cloud approach and web } \\
\text { orientation in percentage }\left(\mathrm{C}_{5}\right)\end{array}$ & 0,100136 \\
\hline $\begin{array}{l}\text { Assessment of compliance with HIPPA } \\
\text { principles on a scale of 0-10 }\left(\mathrm{C}_{6}\right)\end{array}$ & 0,043170 \\
\hline
\end{tabular}

Bearing in mind the fact that during the process of prioritisation inconsistencies of decision makers may occur the AHP provides the possibility to quantify the resulting error by determining the index of consistency and degree of consistency. Consistency index is calculated on the basis of consistency measure, which is obtained by applying the function MMULT in Microsoft Excel, MS Office. Obtained results are given in Table 7:

Table 7. Calculation of the priority vector and consistency measure $(\lambda)$

\begin{tabular}{|c|c|c|c|c|c|c|c|c|}
\hline & $\mathbf{C}_{\mathbf{1}}$ & $\mathbf{C}_{\mathbf{2}}$ & $\mathbf{C}_{\mathbf{3}}$ & $\mathbf{C}_{\mathbf{4}}$ & $\mathbf{C}_{\mathbf{5}}$ & $\mathbf{C}_{\mathbf{6}}$ & $\mathbf{W}_{\mathbf{j}}$ & $\boldsymbol{\lambda}$ \\
\hline $\mathbf{C}_{\mathbf{1}}$ & 0,202020 & 0,270270 & 0,210526 & 0,16342 & 0,184615 & 0,217391 & 0,208041 & 6,044898 \\
\hline $\mathbf{C}_{\mathbf{2}}$ & 0,202020 & 0,270270 & 0,263158 & 0,32684 & 0,276923 & 0,260870 & 0,266682 & 6,063368 \\
\hline $\mathbf{C}_{\mathbf{3}}$ & 0,050505 & 0,054054 & 0,052632 & 0,05447 & 0,046154 & 0,043478 & 0,050216 & 6,055681 \\
\hline $\mathbf{C}_{\mathbf{4}}$ & 0,404040 & 0,270270 & 0,315789 & 0,32684 & 0,369231 & 0,304348 & 0,331754 & 6,084476 \\
\hline $\mathbf{C}_{\mathbf{5}}$ & 0,101010 & 0,090090 & 0,105263 & 0,08171 & 0,092308 & 0,130435 & 0,100136 & 6,051075 \\
\hline $\mathbf{C}_{\mathbf{6}}$ & 0,040404 & 0,045045 & 0,052632 & 0,04669 & 0,030769 & 0,043478 & 0,043170 & 6,027636 \\
\hline
\end{tabular}

Consistency index is then calculated by formula:

$$
C I=\frac{\lambda_{\max }-n}{n-1}
$$

If the consistency index is less than 0.10 the result is sufficiently accurate and there is no need for adjustments, i.e. the AHP technique tolerates inconsistency of less than $10 \%$. Otherwise, when the consistency index is greater than 0.10 the result should be re-analysed and the reasons for inconsistencies should be identified.

The degree of consistency represents the ratio of consistency index and random index. Random index depends on the number of rows of the matrix, and its values are given in Table 8: 
Table 8. Random index values

\begin{tabular}{|l|l|l|l|l|l|l|l|l|l|}
\hline 1 & 2 & 3 & 4 & 5 & 6 & 7 & 8 & 9 & 10 \\
\hline 0,0 & 0,0 & 0,58 & 0,9 & 1,12 & 1,25 & 1,32 & 1,41 & 1,45 & 1,49 \\
\hline
\end{tabular}

Source: (Saaty, 1980)

Table 9. Consistency index and degree of consistency

\begin{tabular}{|l|l|}
\hline CI & 0,016895162 \\
\hline RI $(n=6)$ & 1,25 \\
\hline$C R=C I / R I$ & 0,013516129 \\
\hline
\end{tabular}

Value of consistency index shown in Table 9 indicates that obtained weighting coefficients are relevant, and can therefore be used in further analysis. Weighted normalised decision matrix is given in Table 10.

Table 10. Weighted normalised decision matrix

\begin{tabular}{|l|l|l|l|l|l|l|}
\hline & \multicolumn{5}{|c|}{ Criteria } \\
\hline Alternative & $\mathrm{C}_{1}$ & $\mathrm{C}_{2}$ & $\mathrm{C}_{3}$ & $\mathrm{C}_{4}$ & $\mathrm{C}_{5}$ & $\mathrm{C}_{6}$ \\
\hline $\begin{array}{l}\text { eClinical } \\
\text { Works }\end{array}$ & 0,1838 & 0,0039 & 0,0227 & 0,2046 & 0,0581 & 0,0743 \\
\hline CureMD & 0,0542 & 0,0117 & 0,0324 & 0,1905 & 0,0511 & 0,0557 \\
\hline $\begin{array}{l}\text { McKesson } \\
\text { Practice } \\
\text { Choice }\end{array}$ & 0,0808 & 0,0086 & 0,0308 & 0,1785 & 0,0634 & 0,0372 \\
\hline
\end{tabular}

The next step of the TOPSIS method encompasses determination of the distance of each alternative from the positive ideal solution and negative ideal solution. The calculated distances are given in Table 11.

Table 11. Distance from the positive ideal solution and negative ideal solution

\begin{tabular}{|l|l|l|}
\hline Alternative & $S_{i}^{*}$ & $S_{i}^{-}$ \\
\hline
\end{tabular}




\begin{tabular}{|l|r|r|}
\hline eClinical Works & 0,01354 & 0,13240 \\
\hline CureMD & 0,13094 & 0,01734 \\
\hline $\begin{array}{l}\text { McKesson Practice } \\
\text { Choice }\end{array}$ & 0,10627 & 0,03080 \\
\hline
\end{tabular}

On the basis of the calculated distance proximity index can be determined. Proximity index is necessary for determination of the ranking of alternatives. The results are given in Table 12.

Table 12. Proximity index and alternative ranks

\begin{tabular}{|l|c|c|}
\hline Alternative & Index value & Alternative rank \\
\hline eClinical Works & 0,90723 & 1 \\
\hline CureMD & 0,11693 & 3 \\
\hline $\begin{array}{l}\text { McKesson Practice } \\
\text { Choice }\end{array}$ & 0,22470 & 2 \\
\hline
\end{tabular}

As already mentioned, the TOPSIS method determines the order of alternatives on the basis of similarity to ideal solution, where an ideal solution is the one that fully meets all the criteria. Since an ideal solution in real life is untenable, the optimal solution is adopted and that is actually a solution which at the greatest possible extent satisfies all the criteria. In this case it is a health information system called eClinical Works. The TOPSIS method does not provide a specific measure of efficiency but it gives the order of alternatives on the basis of which it can be concluded which of the alternative is the best, and therefore the most efficient. The obtained result gives an idea which information system is optimal in given circumstances. Change of circumstances, primarily in terms of changes in assessment of criteria, would require a re-evaluation.

\section{Conclusion}

Evaluation and selection of the information systems is demanding and time consuming task. Problems such as detecting software evaluation criteria, creating criteria hierarchy, defining adequate measures and application of comprehensive methodology for facilitating decision-making process arise frequently. This paper provides an overview of all the aspects that must be taken into consideration during the process of selecting an appropriate information system. The evaluation of 
health information systems was conducted in the case of three most widely used softwares in the electronic health care and it was based on multi-criteria analysis of the health information systems efficiency using the AHP-TOPSIS method. This method, based on the identified criteria and its measures has determined the order of alternatives and identified the best ranked software solution among given alternatives. The applied method does not provide an exact efficiency measure but it offers the decision-makers the information about the ranks of the analysed alternatives. Based on the obtained ranks, decision-makers can conclude which of the alternatives is the best, and therefore the most efficient. The best rated software solution is not necessarily the best for the implementation and development, given the fact that each health care organisation has its own characteristics but it gives an idea which software solution is optimal in certain situation.

\section{References}

Ahmadi, H., Rad, M. S., Nazari, M., Nilashi, M., \& Ibrahim, O. (2014). Evaluating the factors affecting the implementation of hospital information system (HIS) using AHP method. Life Science Journal, 11(3), 202-207.

Arnesen, T., \& Trommald, M. (2004). Roughly right or precisely wrong? Systematic review of quality-of-life weights elicited with the time trade-off method. Journal of health services research \& policy, 9(1), 43-50.

Barron, F. H., \& Barrett, B. E. (1996). The efficacy of SMARTER-Simple multi-attribute rating technique extended to ranking. Acta Psychologica, 93(1), 23-36.

Bottomley, P. A., \& Doyle, J. R. (2001). A comparison of three weight elicitation methods: good, better, and best. Omega, 29(6), 553-560.

Bottomley, P. A., Doyle, J. R., \& Green, R. H. (2000). Testing the reliability of weight elicitation methods: direct rating versus point allocation. Journal of Marketing Research, 37(4), 508-513.

Chin, K. S., Fu, C., \& Wang, Y. (2015). A method of determining attribute weights in evidential reasoning approach based on incompatibility among attributes. Computers \& Industrial Engineering, 87, 150-162.

Colombo, E., \& Francalanci, C. (2004). Selecting CRM packages based on architectural, functional, and cost requirements: Empirical validation of a hierarchical ranking model. Requirements Engineering, 9(3), 186-203.

Curtis, I. A. (2004). Valuing ecosystem goods and services: a new approach using a surrogate market and the combination of a multiple criteria analysis and a Delphi panel to assign weights to the attributes. Ecological Economics, 50(3), 163-194.

Danaher, P. J. (1997). Using conjoint analysis to determine the relative importance of service attributes measured in customer satisfaction surveys. Journal of Retailing, 73(2), 235-260.

Dehghan-Manshadi, B., Mahmudi, H., Abedian, A., \& Mahmudi, R. (2007). A novel method for materials selection in mechanical design: combination of non-linear normalization and a modified digital logic method. Materials \& Design, 28(1), 815. 
Deng, H., Yeh, C. H., \& Willis, R. J. (2000). Inter-company comparison using modified TOPSIS with objective weights. Computers \& Operations Research, 27(10), 963973.

Diakoulaki, D., Mavrotas, G., \& Papayannakis, L. (1995). Determining objective weights in multiple criteria problems: the CRITIC method. Computers \& Operations Research, 22(7), 763-770.

e Costa, C. A. B., \& Vansnick, J. C. (1997). A theoretical framework for measuring attractiveness by a categorical based evaluation technique (MACBETH). In Multicriteria Analysis (pp. 15-24). Springer Berlin Heidelberg.

Edwards, W., \& Barron, F. H. (1994). SMARTS and SMARTER: Improved simple methods for multiattribute utility measurement. Organizational behavior and human decision processes, 60(3), 306-325.

Edwards, W., \& Barron, F. H. (1994). SMARTS and SMARTER: Improved simple methods for multiattribute utility measurement. Organizational behavior and human decision processes, 60(3), 306-325.

Huang, J. (2008). Combining entropy weight and TOPSIS method for information system selection. In 2008 IEEE Conference on Cybernetics and Intelligent Systems, 12811284

Hwang, C. L., \& Yoon, K. (1981). Multiple attribute decision making making: methods and applications. Berlin: Springer-Verlag.

Jadhav, A. S., \& Sonar, R. M. (2009). Evaluating and selecting software packages: A review. Information and software technology, 51(3), 555-563.

Janković-Milić, V., \& Stanković J. (2010). Bayesian approach to multi-criteria analysis in business decision making (in Serbian). Vrnjačka Spa

Jayant, A., Gupta, P., Garg, S. K., \& Khan, M. (2014). TOPSIS-AHP based approach for selection of reverse logistics service provider: a case study of mobile phone industry. Procedia Engineering, 97, 2147-2156.

Karande, P., \& Chakraborty, S. (2014). A facility layout selection model using MACBETH method. In Proceedings of the 2014 International Conference on Industrial Engineering and Operations Management, January (pp. 7-9).

Kim, J., \& Moon, J. Y. (1997). An AHP \& survey for selecting workflow management systems. Intelligent Systems in Accounting, Finance and Management, 6(2), 141 161.

Kim, K. Y., \& Na, K. S. (2014). Business information system recovery priority decision using TOPSIS on interval data. Journal of Systems and Information Technology, 16(2), 103-112.

Krstic, B., Petrovic, J., \& Stanisic, T. (2015). Analysis of key indicators of economic dimensions of spas'sustainable development in Serbia as tourism destinations 4. Ekonomika, 61(3), 61.

Kundakc1, N. (2016). Combined Multi-Criteria Decision Making Approach Based On Macbeth And Multi-MOORA Methods. Alphanumeric Journal, 4(1).

Kundakc1, N., \& Işı1k, A. (2016). Integration of MACBETH and COPRAS methods to select air compressor for a textile company. Decision Science Letters, 5(3), 381-394.

Lee, J. W., \& Kim, S. H. (2000). Using analytic network process and goal programming for interdependent information system project selection. Computers \& Operations Research, 27(4), 367-382. 
Ma, J., Fan, Z. P., \& Huang, L. H. (1999). A subjective and objective integrated approach to determine attribute weights. European Journal of Operations Research, 112 (2), 397-404.

Milićević, M.R. \& Župac, G.Ž. (2012). Objektivni pristup određivanju težina kriterijuma. Vojnotehnički glasnik, 60(1), 39-56.

Mitchell, J. (2000). Increasing the cost-effectiveness of telemedicine by embracing ehealth. Journal of telemedicine and telecare, 6(suppl 1), 16-19.

Ngai, E. W., \& Chan, E. W. C. (2005). Evaluation of knowledge management tools using AHP. Expert systems with applications, 29(4), 889-899.

Pan American Health Organization (1998) Information Systems and Information Technology in Health: Challenges and Solutions for Latin America and the Caribbean, Health Services Information Systems Program, PAHO/WHO, Washington, DC; ISBN 9275122466.

Podvezko, V., \& Sivilevičius, H. (2013). The use of AHP and rank correlation methods for determining the significance of the interaction between the elements of a transport system having a strong influence on traffic safety. Transport, 28(4), 389-403.

Pöyhönen, M., \& Hämäläinen, R. P. (2001). On the convergence of multiattribute weighting methods. European Journal of Operational Research, 129(3), 569-585.

Pulipati, S. B., \& Mattingly, S. P. (2013). Establishing criteria and their weights for evaluating transportation funding alternatives using a Delphi survey.Procedia-Social and Behavioral Sciences, 104, 922-931.

Rao, R. V. (2008). A decision making methodology for material selection using an improved compromise ranking method. Materials \& Design, 29(10), 1949-1954.

Rao, R. V., \& Davim, J. P. (2008). A decision-making framework model for material selection using a combined multiple attribute decision-making method. The International Journal of Advanced Manufacturing Technology, 35(7-8), 751-760.

Roberts, R., \& Goodwin, P. (2002). Weight approximations in multi-attribute decision models. Journal of Multi-Criteria Decision Analysis, 11(6), 291-303.

Rodrigues, R. J. (2000, April). Telemedicine and the transformation of healthcare practice in the information age. In Speakers' book of the International Telecommunication Union (ITU) Telecom Americas. Rio de Janeiro: Telecom Development Symposium, Session TDS (Vol. 2, pp. 91-105).

Rodrigues, R. J. (2003). Opportunities and challenges in the deployment of global e-health. International journal of healthcare technology and management, 5(3-5), 335-358.

Saaty, T. L. (1977). A scaling method for priorities in hierarchical structures. Journal of mathematical psychology, 15(3), 234-281.

Saaty, T. L. (1990). How to make a decision: the analytic hierarchy process. European Journal of Operational Research, 48 (1), 9-26.

Saaty, T.L. (1980). The Analytic Hierarchy Process, New York: McGraw Hill.

Srđević, B. (2005). Nepristrasna ocena značaja krtierijuma u višekriterijumskoj optimizaciji. Vodoprivreda, 37 (1-3), 53-58.

Tan, J., \& Payton, F. C. (2010). Adaptive health management information systems: Concepts, cases, \& practical applications. Jones \& Bartlett Learning.

Teltumbde, A. (2000). A framework for evaluating ERP projects. International journal of production research, 38(17), 4507-4520.. 
Todorović, O., \& Stanković, J. (2011). TOPSIS metoda kao sredstvo optimizacije odlučivanja u uslovima krize. Nauka i svetska ekonomska kriza, Niš: Ekonomski fakultet

Von Winterfeldt, D., \& Edwards, W. (1986). Decision analysis and behavioral research: Vol. 604. Cambridge: Cambridge University Press.

Wei, C. C., Chien, C. F., \& Wang, M. J. J. (2005). An AHP-based approach to ERP system selection. International journal of production economics, 96(1), 47-62.

Wu, J., Sun, J., Liang, L., \& Zha, Y. (2011). Determination of weights for ultimate cross efficiency using Shannon entropy. Expert Systems with Applications, 38(5), 51625165.

$\mathrm{Xu}, \mathrm{X}$. (2004). A note on the subjective and objective integrated approach to determine attribute weights. European Journal of Operational Research, 156(2), 530-532.

Yoon, K., Hwang, C. (1995). Multiple attribute decision-making: an introduction. Sage Publisher

Zaidan, A. A., Zaidan, B. B., Al-Haiqi, A., Kiah, M. L. M., Hussain, M., \& Abdulnabi, M (2015). Evaluation and selection of open-source EMR software packages based on integrated AHP and TOPSIS. Journal of biomedical informatics, 53, 390-404.

Zavadskas, E. K., \& Podvezko, V. (2016). Integrated Determination of Objective Criteria Weights in MCDM. International Journal of Information Technology \& Decision Making, 15(02), 267-283.

\section{PRIMENA INTREGRISANOG AHP-TOPSIS METODA U OCENI EFIKASNOSTI ZDRAVSTVENIH INFORMACIONIH SISTEMA}

Apstrakt: Cilj ovog rada jeste analiza i ocena efikasnosti zdravstvenih informacionih sistema $u$ pružanju usluga zdravstvene zaštite. Naime, evaluacija zdravstvenih informacionih sistema sprovodi se na primeru tri najčešce korišćenih softvera u elektronskom zdravstvu. Ova evaluacija bazira se na višekriterijumskoj analizi efikasnosti zdravstvenih informacionih sistema pomoću AHP-TOPSIS metoda. Ovim metodom se na osnovu zajedničkih atributa i njihovih pojedinačnih vrednosti za sva tri softverska rešenja ponaosob određuje najbolje rangirano softversko rešenje. Najbolje rangirano softversko rešenje elektronskog zdravstva nije nužno i najbolje za implementaciju i razvoj, s obzirom na to da svaka zdravstvena organizacija ima svoje specifičnosti. Funkcionalna i evolutivno nastrojena hardverska i softverska infrastruktura doprinosi aplikativnoj konzistentnosti koncepta elektronskog zdravstva što svim korisnicima sistema pruža komforniju primenu softverskog rešenja, što u konačnom vodi ka pružanju pravovremenih i brzih zdravstvenih usluga u realnom vremenu.

Ključne reči: višekriterijumska analiza, elektronsko zdravstvo, AHP, TOPSIS, upravljanje zdravstvenim informacionim sistemima, efikasnost. 


\section{Authors' biographies}

Žarko Rađenović graduated from the Faculty of Economics in 2012 . He received his M.Sc. (2013) and became a $\mathrm{PhD}$ student (2013) at the Faculty of Economics in Niš. Starting from the 2015/2016 school year he works as a demonstrator at the Faculty of Economics, University of Niš. He is the author of many scientific papers for domestic and international journals and conferences.He is a scholar of the Ministry of Education, Science and Technological Development. His fields of interest include informatics in economics, electronic business, health economics and management of information systems.

Ivana Veselinović graduated from the Faculty of Economics, University of Nis in September 2012, the module Accounting, Auditing and Financial Management. She defended her Master's thesis in the scientific field economic statistics, the application of mathematical and statistical methods in economic research. Currently, she is a $\mathrm{PhD}$ student at the Faculty of Economics, University of Niš. She is a scholar of the Ministry of Education, Science and Technological Development. Starting from the 2013/2014 school year, she works as a demonstrator at Faculty of Economics in Niš. Key areas of her interest include multi-criteria decision-making and optimisation. 